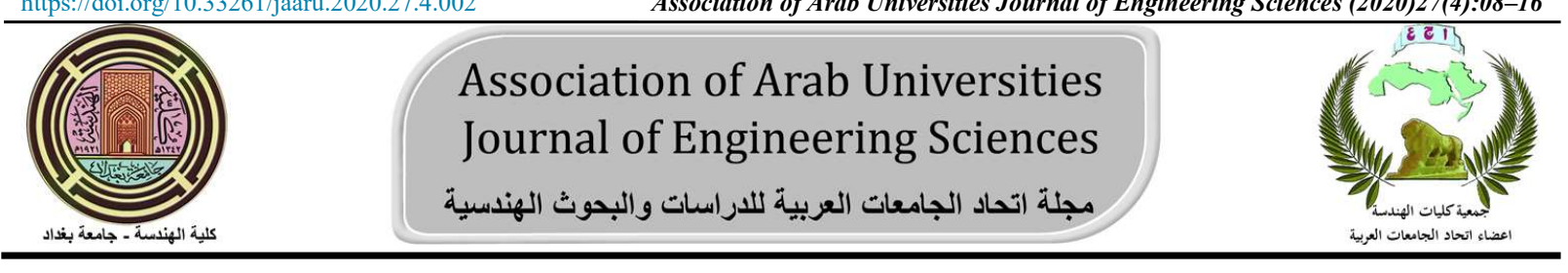

\title{
Processing of Iraqi Attapulgite For Using as Drilling Muds: A Comparison Study
}

\author{
Ahmed Flayyih Hussein ${ }^{1, *}$, Abd Al Khalaq F. H. ${ }^{2}$, Asswer A. AL Wassity ${ }^{3}$ \\ ${ }^{1}$ Department of Production and Metaluregy Engineering, University of Technology, Baghdad, Iraq, Afh_uot@yahoo.com \\ ${ }^{2}$ Department of Production and Metaluregy Engineering, University of Technology, Baghdad, Iraq, \\ ${ }^{3}$ Department of Petroleum Engineering, University of Technology, Baghdad, Iraq.150003@uotechnology.edu.iq \\ *Corresponding author: Ahmed Flayyih Hussein Afh_uot@yahoo.com \\ Published online: 31 December 2020
}

Abstract-Clay mineral processing is in charge on quality, quantity and functional properties of final produced clay. In this work, Iraqi attapulgite (Palygorskite) clay was processed with dry sieving, dispersing agent and wet sieving processes to make it suitable in oil and gas wells drilling fluids preparation. Yield of clay (quality) and yield of process (quantity) were taken as preferring criteria in choosing the proper process of Iraqi attapulgite clay preparation. XRD and FESEM tests were used for mineralogical and morphological identification respectively. OFITE viscometer was used to measure the rheological properties of the drilling fluids prepared with the produced attapulgite from the investigated processes. The results of this work showed that dry sieving process was failed in attapulgite separation. Moreover, dry grinding was a destructive process of the attapulgite crystalline structure which reduced the rheological properties up to $80 \%$. The results showed that the dispersing agents process produces attapulgite clay with higher quality (101.94 and 89.87 barrle/ton) with fresh and salt water respectively and at low quantity of about $7 \%$. While wet sieving process produces attapulgite clay with quality equals to $(94.21$ and 79.93 barrel/ton) with fresh and salt water respectively and quantity reaching $40 \%$. It follows that wet sieving was the recommended process in preparing Iraqi attapulgite to be suitable for oil and gas wells drilling fluid.

Keywords: - Iraqi attapulgite, dry sieving, wet sieving, dispersing agents, rheological properties.

\section{Introduction}

Mineral processing is a main branch in the science of Extractive Metallurgy. Extractive metallurgy can be defined as the science and art of extracting minerals from their ores, purifying and preparing them for the required applications [14]. Generally, mineral processing consists of two main primary operations comminution and concentration as well as other consecutive secondary processes involved in mineral processing like sampling and dewatering [4]. However, the essential targets for mineral processing are liberate (by size reduction) and concentrate (separation) minerals from their ore through applying suitable mechanical treatment, these two targets are achieved successively to obtain the desired end product and with high economic feasibility [8,14].

In petroleum sector, drilling fluid is used during drilling process for many purposes such as lubrication, cooling, cleaning the drill hole, etc. Bentonite is the main content of drilling fluid. In Iraqi petroleum sector, this bentonite imports from other countries. Indeed, during drilling through salt formation, the drilling fluid lost its activity and to solve this some chemical additives should be added to it. Currently Iraqi national drilling company searches for other local materials. Hence, the aim of this work is to find an acceptable local alternative material to tackle the above issues. The attapulgite (Palygorskite) clay was suggested as new local alternative for two reasons. First, attapulgite clay has lower sensitivity to salt concentrations, in other word; the desired rheological properties keep relatively constant even at high electrolyte concentrations. Second, Attapulgite clay is so available in many Iraqi regions (Bahar AL Najaf region and Akashat deposit). There are many methods used to separate quartz from attapulgite as well as increasing its purification. The selection of the proper and suitable separation process is not an easy matter, therefore; quality and quantity were adopted as criteria to assist in process selection. 


\section{Experimental work}

\subsection{Materials}

Samples of attapulgite rock were taken from the Bahar AL Najaf region in the Iraqi western desert. Tetrasodium pyrophosphate $\left(\mathrm{Na}_{4} \mathrm{P}_{2} \mathrm{O}_{7}\right)$ purchased from Rommel co. Germany. magnesium hydroxide $\mathrm{Mg}(\mathrm{OH})_{2}$ purchased from CDH Co. - India. acetic acid purchased from Alpha Chemika - India, distilled and deionized water purchased from Al-Mansoura Co.- Iraq.

\subsection{Samples preparation}

Three processes were applied to separate quartz from attapulgite clay, dry sieving, dispersing agents and wet sieving process. The operating parameters (milling speed, milling time, stirring speed, stirring time, mesh size, and acid type and its concentration) for each process were fixed through other separating works.

\section{Dry sieving process}

According to particles size, soil was_classified into gravel $(>2 \mathrm{~mm})$, sand $(2-0.05 \mathrm{~mm})$, silt $(0.05-0.002 \mathrm{~mm})$, clay $(<0.002 \mathrm{~mm})$ [2]. This classification was invested in quartz separation process from clay using dry or wet sieving process.

In this work, dry sieving process was implemented through the following steps, first, attapulgite rocks were crushed to $\leq 1 \mathrm{~cm}^{3}$ particles size by using jaw crusher machine. Second, crushed attapulgite was dried at $105^{\circ} \mathrm{C}$ for 3 hours using Binder drying oven. Third, dried attapulgite was milled by ball mill machine at 300rpm for 15 minutes. Later, sieving process was carried out at different mesh sizes $(38,53$ and $75 \mu \mathrm{m})$ by vibratory sieve for 5minuts. Figure 1 shows the process layout for dry sieving process.

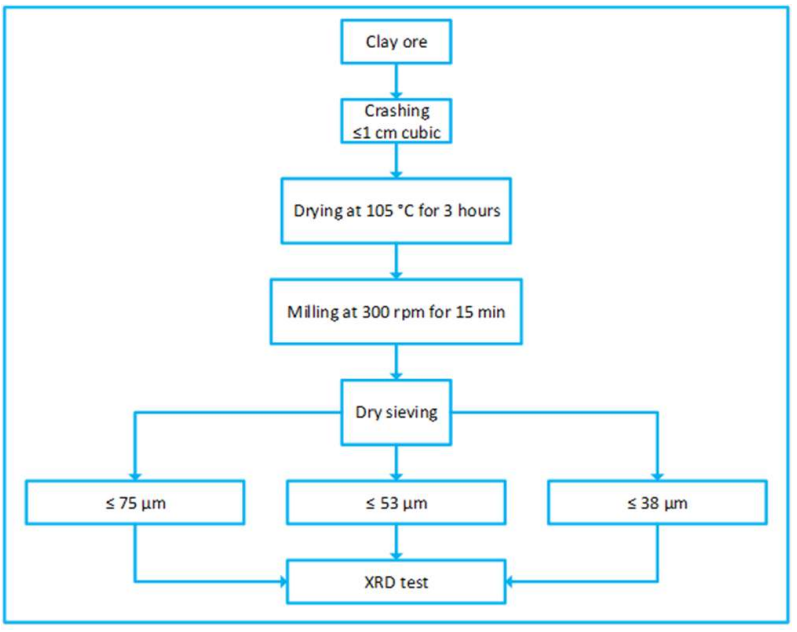

Figure 1: Process layout for dry sieving process.

\section{Dispersing agents process}

The quartz was separate from attapulgite clay using dispersing agents process. According to particles size; two types of attapulgite raw were used, crushed clay $\leq 1 \mathrm{~cm}^{3}$ and milled clay $\leq 75 \mu \mathrm{m}$. In this process, $2.8 \mathrm{~g}$ of tetra sodium pyrophosphate was dissolved with $432 \mathrm{ml}$ of deionize water with stirring velocity $720 \mathrm{rpm}$ for 1 minute. Then $1.4 \mathrm{~g}$ of $\mathrm{Mg}(\mathrm{OH})_{2}$ was added with continues stirring for another 1 minute. $140 \mathrm{~g}$ of dry attapulgite raw was also added gradually. The mixing was agitated for 5 minutes at $720 \mathrm{rpm}$ and for 5 minutes at $920 \mathrm{rpm}$. The resultant suspension was poured into a half gallon jar. Deionized water $(700 \mathrm{ml})$ was added to the jar and the suspension were stirred for 5 minutes at $920 \mathrm{rpm}$. The obtained suspension was left to precipitate for (3- 5) hours [9].

The final produced suspension, contains $(+3 \mu \mathrm{m})$ particles; was wet sieved at $38 \mu \mathrm{m}$ mesh size then poured in to stainless steel pan and dried by Binder drying oven at $105^{\circ} \mathrm{C}$ for sufficient time ( 3 hours). Then the obtained clay was acid treated to remove calcite mineral. Figure 2 shows the process layout of dispersing agents process.

\section{Wet sieving process}

Wet sieving was utilized to separate quartz from attapulgite clay based on particle size. In this work, crushed attapulgite raw $\left(\leq 1 \mathrm{~cm}^{3}\right)$ was wet milled at solid / liquid ratio 1 to $10 \mathrm{wt} . / \mathrm{v}$ using full nutrition broken machine. The mixing was stirred at $1800 \mathrm{rpm}$ for 20 minutes then wet sieved within $38 \mu \mathrm{m}$ mesh size. Finally, thermal dewatering was implemented using Binder drying oven at $105^{\circ} \mathrm{C}$ for 3 hours. Then the attapulgite clay was concentrated by acid treatment. Figure 3 shows the process layout for wet sieving process.

\subsection{Acid treatment Process}

Purification process was adopted to remove calcite mineral from attapulgite produced from the above processes (dispersing agentsand wet sieving). This process was implemented in the following sequence $[10,11]$. i) adding separated attapulgite clay to $1.138 \mathrm{M}$ acetic acid at liquid / solid ratio 10 to $1 \mathrm{v} / \mathrm{w}$ in glass container under mechanical stirring $(800 \mathrm{rpm})$ at room temperature forlhour. $\mathrm{ii}$ ) washing with distilled water

until $\mathrm{pH}$ values be 7.iii) wet sieving process was applied at $38 \mu \mathrm{m}$ mesh size. Finally, the achieved attapulgite clay was dried at $105^{\circ} \mathrm{C}$ for (3hours).

\subsection{Yield of Process Measurement}

The yield of process test aimed to measure the quantity of the obtained clay from each separation process. However; the obtained clay has attapulgite majority, which qualified it to use as viscosifier in oil and gas wells drilling fluid. The yield of process was measured by taking the weight of purified clay to the weight of the input raw and applied in equation 1. The yield of each 
Separation process was measured three times and the average result was adopted.

Yield of process $=\frac{\text { output weig }}{\text { input weig }} * 100$

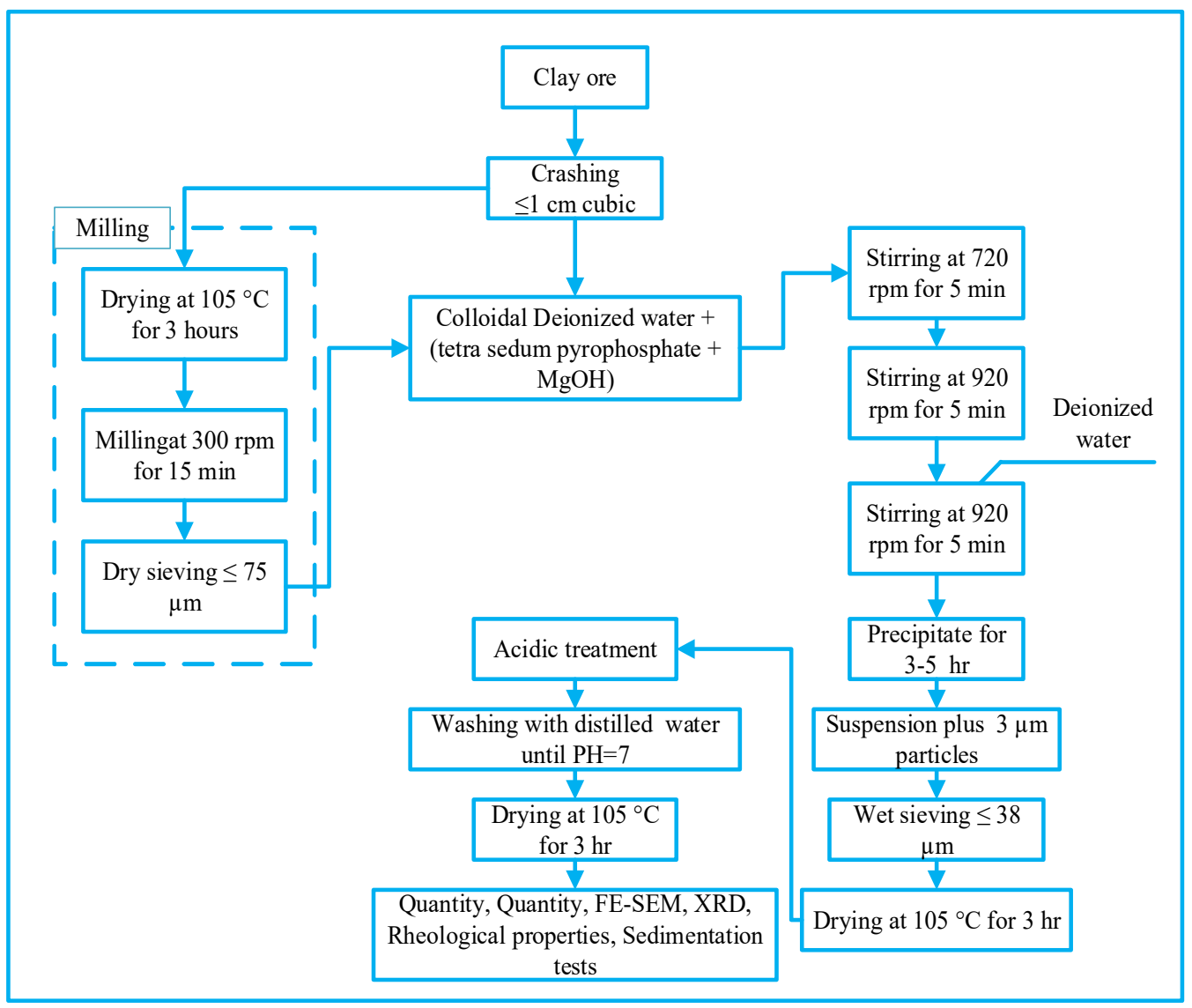

Figure 2: Process layout of Dispersant agents' process. 


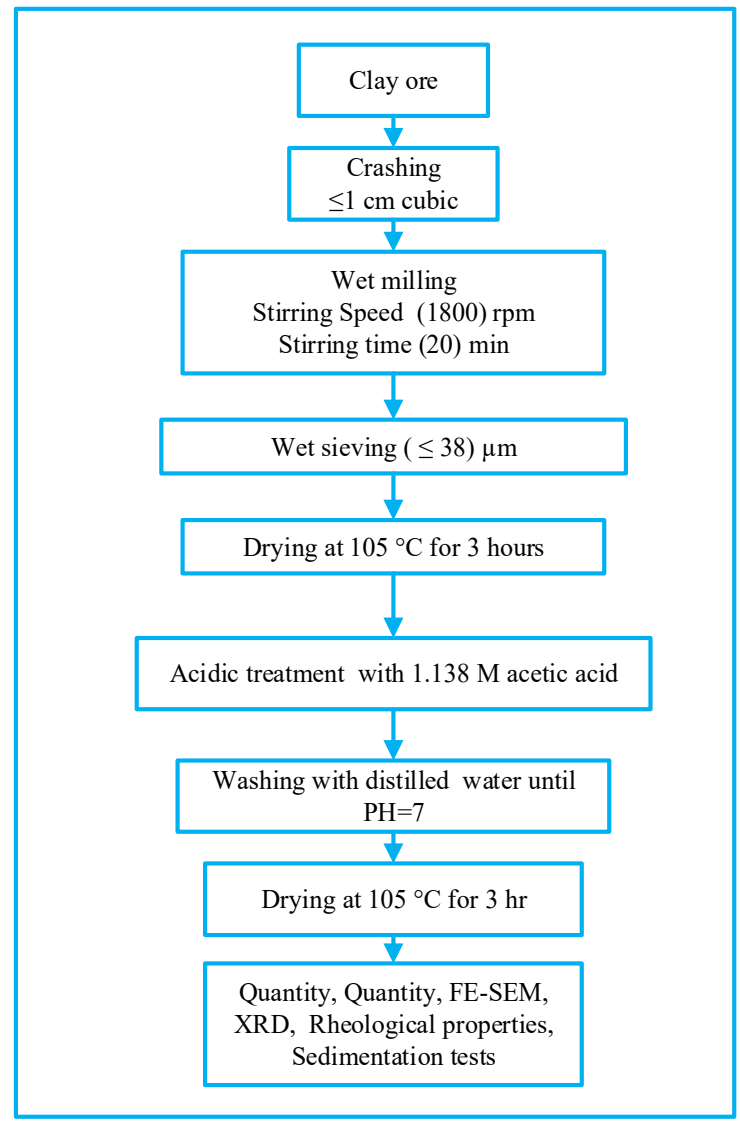

Figure 3: process layout for wet sieving process

\subsection{Mineral Test}

The mineral analysis

of produced attapulgite were carried out using X-Ray diffraction test, which implemented by using SHIMADZU X-ray - 6000Diffractometer at Nanotechnology and Advanced Materials Research Center, University of Technology- Iraq. While, the minerals were quantified by using ICDD's PDF-4+ - Phase Identification \& Quantitation software at Iraqi-Germany lab, geology department/Baghdad University - Iraq. The morphology and distribution of attapulgite within samples were diagnosed by HITACHI S-4160 Field Emission Scanning Electron Microscope at the electrical and computer engineering department, Tehran University- Islamic Republic of Iran.

\subsection{Rheological Properties Measurements}

In this work, the rheological properties (apparent viscosity, plastic viscosity, yield point and gel strength) for produced attapulgite was tested by OFITE viscometer model 900 with 12 speed. Water-based drilling fluid with 6 wt.\% attapulgite was prepared according to API classification. This was done by taking $22.5 \mathrm{~g}$ of purifielassification $(22.5 \mathrm{~g}$ clay with $350 \mathrm{ml}$ distilled or salt water) using Waring Blender at low speed for $20 \mathrm{~min}$.
After mixing, the drilling fluid was left to hydrate for 18 hours at room temperature. Later; drilling fluid was reagitated at low stirring speed for 5 minutes before measuring shear stress versus shear rate of drilling fluid were calculated through equations 2,3 and $4[3]$. The test was repeated three times and the average value was adopted.

$$
\begin{array}{ll}
\text { Apparent viscosity (AV) } & =0.5 \Theta 600 \mathrm{cP} \\
\text { Plastic viscosity (PV) } & =\Theta 600-\Theta 300 \mathrm{cP} \\
\text { Yield Point (YP) } & =0.511(\Theta 300-\mathrm{PV}) \mathrm{pa}
\end{array}
$$

\subsection{Yield of Clay Measurement}

In this work, yield of clay was identified by measuring apparent viscosity for drilling fluid at different clay concentration $(3,6,9$ and $12 \mathrm{wt} \%)$ at fresh and salt water. the relationship between clay content (wt \%) and apparent viscosity (cp) was drawn. The clay content (wt $\%$ ) which intersect with apparent viscosity at $15 \mathrm{cp}$ represents $x$ value [6]. The yield of clay was calculated from equations 5 and 6 for fresh and salt water respectively.

$$
\begin{aligned}
& \text { Yield of clay }=\frac{570.287}{x}-3.079 \\
& \text { Yield of clay }=\frac{556.947}{x}-2.946
\end{aligned}
$$


Where $\mathrm{x}=$ weight of added clay/ $\left(350 \mathrm{~cm}^{3} * \rho_{\mathrm{w}} \mathrm{g} / \mathrm{cm}^{3}+\right.$ weight of added clay $(\mathrm{g}))$.

\section{Result and discussion}

\subsection{XRD analysis}

Table 1shows the mineral analysis of the raw attapulgite rock, high calcite and quartz contains within attapulgite rock is observed as shown in table 1 .

Table 1: The mineral analysis for attapulgite rock

\begin{tabular}{|c|c|c|c|c|c|c|c|}
\hline $\begin{array}{c}\text { Mine } \\
\text { rals }\end{array}$ & $\begin{array}{c}\text { Cal } \\
\text { cite }\end{array}$ & $\begin{array}{c}\text { Qua } \\
\text { rtz }\end{array}$ & $\begin{array}{c}\text { Attap } \\
\text { ulgite }\end{array}$ & $\begin{array}{c}\text { Illi } \\
\text { te }\end{array}$ & $\begin{array}{c}\text { Hal } \\
\text { ite }\end{array}$ & $\begin{array}{c}\text { Chlo } \\
\text { rite }\end{array}$ & $\begin{array}{c}\text { Alb } \\
\text { ite }\end{array}$ \\
\hline$\%$ & 37.8 & 25.7 & 9.9 & $\begin{array}{c}8 . \\
3\end{array}$ & 3 & 6.3 & 9.1 \\
\hline & & & & 3 & & \\
\hline
\end{tabular}

Table2 shows X-ray diffraction analysis for the obtained raw material after dry sieving at different particle size (38, 53 and $75 \mu \mathrm{m})$. The results show that dry sieving inefficiently process to concentrate or separate attapulgite clay at certain sieve size, this could be due to many reasons. First, for particles $<75 \mu \mathrm{m}$ (clay particles size $<2$ $\mu \mathrm{m})$; the surface forces (cohesion and adhesion) will be dominant therefore clay particles will stick to the sieve and stick to the surface of the quartz particles. Second, the light particle (clay particles) will be attracted to each other causing clay particles agglomeration. Third, its light weight does not provide sufficient force during sieving to fragment those agglomerate [17]. Therefore; fragments quartz remains with attapulgite clay and did not separated. In this work, dry milling contributes in particle size reduction but could not strip clay from quartz particles. So, the dry sieving process has been ruled out as a separation process for attapulgite clay.

For dispersing agents process, table 3 shows the mineral analysis for separated raw clay (crushed and milled).in this process, the low quartz percentage (13\%) within separated clays (crushed and milled) indicated the success of the dispersing agents process in separating quartz from attapulgite clay. Besides, calcite mineral was existed in high and close percentages for both crushed and milled clay; this is because calcite brittleness made it easy to mill with very fine particle size. Also, calcite mineral has theoretical density $\left(2.7102 \mathrm{~g} / \mathrm{cm}^{3}\right)$ approaching the attapulgite density $\left(2.5 \mathrm{~g} / \mathrm{cm}^{3}\right)$ [7,12]. These two reasons made calcite dispersed with attapulgite mineral within suspension at high percentage reaching up to $50 \%$.
Table2: Mineral analysis of separated sample with dry sieving process.

\begin{tabular}{|c|c|c|c|c|}
\hline & $\underline{\underline{\mathrm{Raw}}} \underline{\text { material }}$ & $\begin{array}{l}\frac{\text { Sieve }}{\leqq} \\
75 \mu \mathrm{m}\end{array}$ & $\begin{array}{l}\frac{\text { Sieve }}{\leqq} \\
\underline{53 \mu \mathrm{m}}\end{array}$ & $\begin{array}{c}\frac{\text { Sieve }}{\leqq} \\
\underline{38 \mu \mathrm{m}}\end{array}$ \\
\hline Calcite & 37.8 & 31.4 & 38.5 & 33.2 \\
\hline Quartz & 25.7 & 51.7 & 31 & 27.6 \\
\hline Palygorskite & 9.9 & 6.1 & 11.3 & 16.4 \\
\hline Illite & 8.3 & 6.1 & 9.8 & 14.4 \\
\hline$\underline{\text { Chlorite }}$ & 6.3 & 1.2 . & 4.3 & - \\
\hline Albite & 9.1 & - & - & - \\
\hline Halite & 3 & - & - & - \\
\hline$\underline{\text { Kaolinite }}$ & - & 3.5 & 5.2 & 8.4 \\
\hline
\end{tabular}

Table3: The mineral analysis for separated clay by dispersing agent's process

\begin{tabular}{|c|c|c|c|c|c|c|c|c|}
\hline $\begin{array}{c}\text { Miner } \\
\text { als }\end{array}$ & $\begin{array}{c}\text { Cal } \\
\text { cite }\end{array}$ & $\begin{array}{c}\text { Qu } \\
\text { artz }\end{array}$ & $\begin{array}{c}\text { At } \\
\text { tp. }\end{array}$ & $\begin{array}{c}\text { Ill } \\
\text { ite }\end{array}$ & $\begin{array}{c}\text { Ha } \\
\text { lite }\end{array}$ & $\begin{array}{c}\text { Ana } \\
\text { tase }\end{array}$ & $\begin{array}{c}\text { Mo } \\
\text { nt. }\end{array}$ & $\begin{array}{c}\text { Chl } \\
\text { orite }\end{array}$ \\
\hline $\begin{array}{c}\text { Crush } \\
\text { ed } \\
\text { clay } \leq \\
1 \mathrm{~cm} 3\end{array}$ & $\begin{array}{c}45 . \\
6\end{array}$ & 13 & $\begin{array}{c}17 \\
.6\end{array}$ & $\begin{array}{c}11 \\
.8\end{array}$ & 8.5 & 2.1 & 1.3 & - \\
\hline $\begin{array}{c}\text { Mille } \\
\text { clay } \\
\leq \\
75 \mu \mathrm{m}\end{array}$ & $\begin{array}{c}42 . \\
1\end{array}$ & $\begin{array}{c}13 . \\
8\end{array}$ & $\begin{array}{c}27 \\
.5\end{array}$ & - & 8.2 & 2 & 5.2 & 1.3 \\
\hline
\end{tabular}

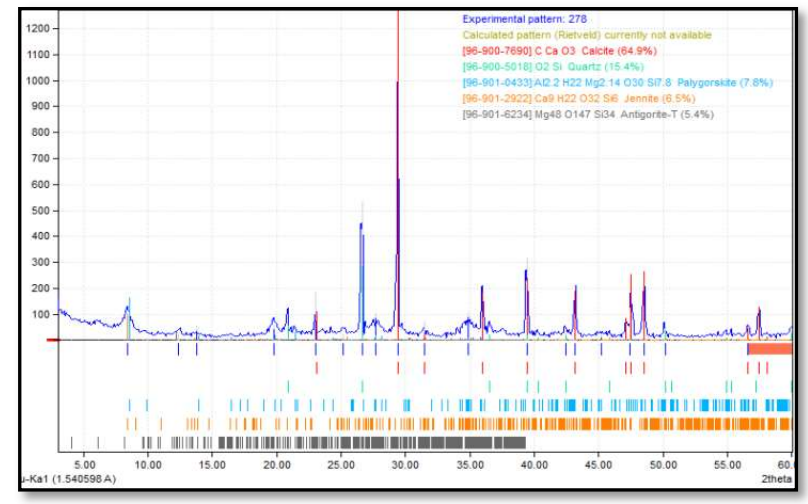

Figure 4: Minerals analysis for obtained clay from wet sieving process.

For wet sieving process; figure 4 shows the high calcite percentage within separated clay, this could be due to two reasons, first wet milling process which reduce calcite particles size below $38 \mu \mathrm{m}$. Second wet sieving process 
remove components with particle size $>38 \mu \mathrm{m}$ specially quartz mineral.

Figure5 shows mineral analysis for purified attapulgite clay resulted from dispersing agents' and wet sieving processes. The results show that the acidic treatment with $1.138 \mathrm{M}$ acetic acid was sufficient to remove whole calcite from separated clay for both above processes.
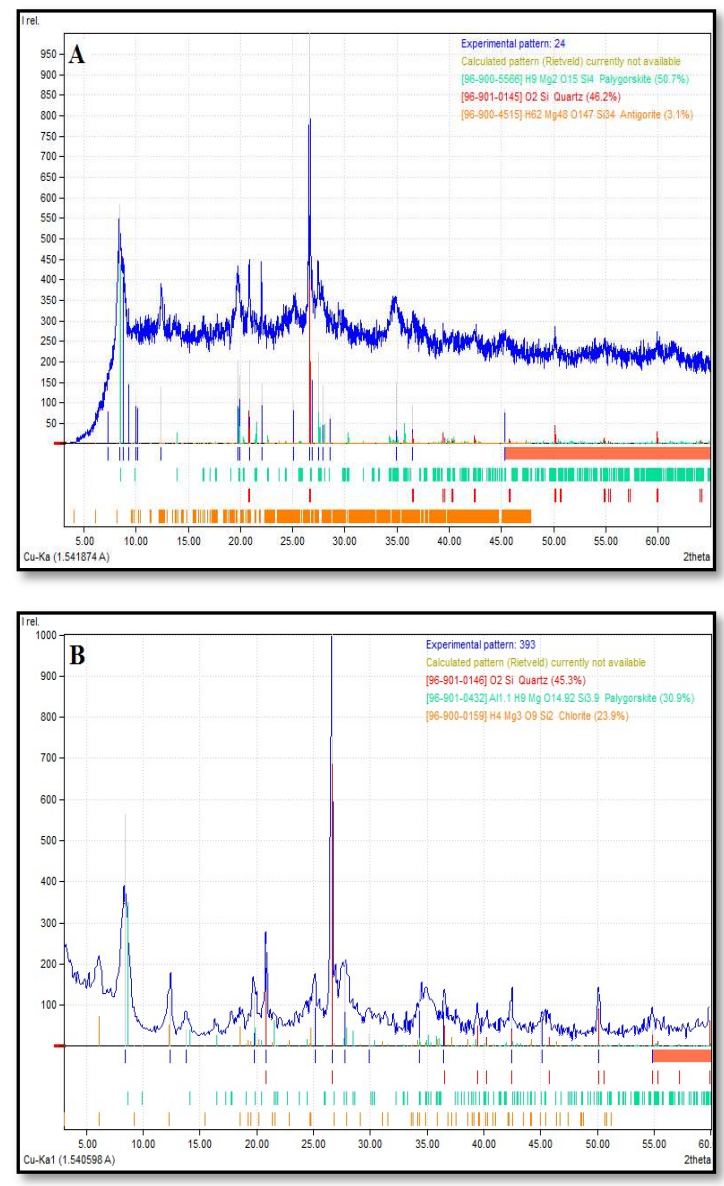

Figure 5: XRD pattern for purified clay (A) dispersant agents process. (B) Wet sieving process.

Moreover, the approached proportion of quartz within the separated clay using dispersing agents and wet sieving processes yields important results: first the quartz particles were in the silt size range. Second dispersing agentsand wet sieving processes did not work well to remove whole quartz from clay. This could be due to the quartz particle size. Where, at dispersing agents process; the silt-size allowed the quartz to be suspended with clay within suspension. While, at wet sieving process; the siltsize quartz was passed through out the utilized sieve $(38 \mu \mathrm{m})$. Originally, the existing of quartz with silt size could be due to the forming nature of Bahar Al-najaf region as sedimentary formation for Euphrates river [15].

\subsection{FESEMimage Result}

The FESEM (Fild Emission Scanning Electron Microscopy) images of the resulted attapulgite from dispersing agents process and wet sieving process are shown in figure 6 . These images clarify the impact of separation process on morphology and distribution of attapulgite clay. The images for crushed clay $\left(\leq 1 \mathrm{~cm}^{3}\right)$ that resulted from dispersing agents process, showed in Figure 6 (e-h). It can be observed that the attapulgite rods are aligned without any damage as long layered bundles, and they are similar to existing rods in raw attapulgite rock which showed in Figure 6(a-d).

For milled clay, the attapulgite rods were very short and it is severely damaged as shown in Figure 6(i-1), this result was due to dry milling process by ball mill machine [13]. Indeed, the short rods were agglomerated in different bulks sizes as a result of the physical bonding force.

For the produced attapulgite from wet sieving process, which are showen in Figure6 (m-q), the attapulgite rods were existed as bundles of long rods in addition to bulky agglomerated rods and there were no significant damages seemed on attapulgite rods.

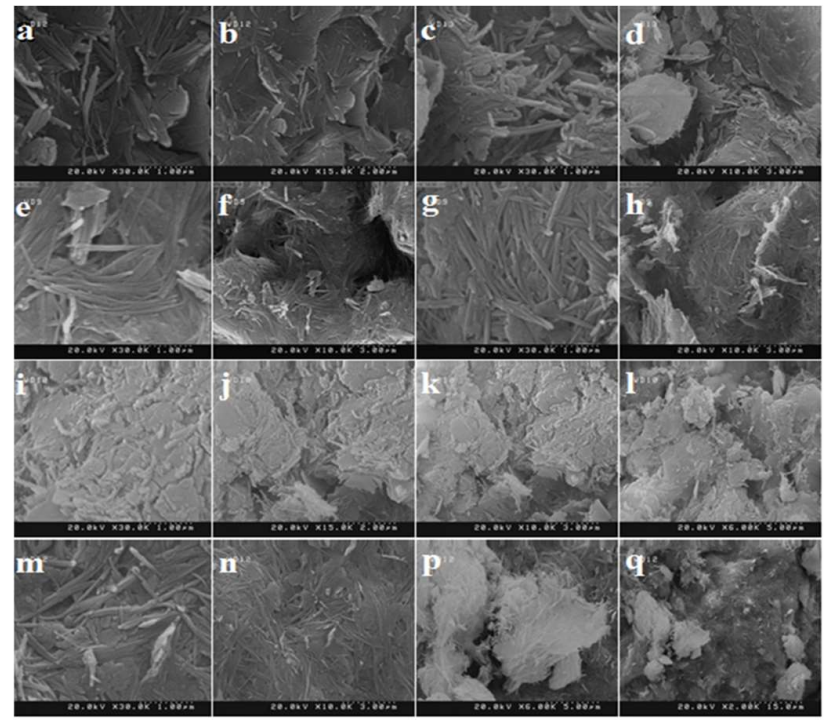

Figure 6: FE-SEM images for attapulgite rock (a-d). Crushed attapulgite (e-h). milled attapulgite (i-l) resulted by dispersant agents' process. Attapulgite resulted by wet sieving $(\mathrm{m}-\mathrm{q})$.

The FESEM images indicate that attapulgite rods produced by wet sieving process were re-agglomerated after wet sieving with $38 \mu \mathrm{m}$ mish size but those produced by dispersing agent process were not. This result may be due to the effect of the used dispersing agents that still work even after drying which prevent attapulgite rods reagglomerating [16]. 


\subsection{Results of Rheological Properties and Yield of Clay.}

The rheological properties and yield of attapulgite clay that resulted from dispersing agents and wet sieving processes are shown in Tables 4, 5, and figure7. Dispersing agents process produced attapulgite clay with high apparent viscosity (19.28 and $15 \mathrm{cp})$ at fresh and salty water respectively for crushed clay raw. While for milled clay raw; the apparent viscosity was (3.15 and3.1 cp) at fresh and salty water respectively. This difference with wide gab in apparent viscosity value was come from the difference in attapulgite aspect ratio (1/d). The FESEM images showed that the crushed clay had long rods with no damage, that means high $1 / \mathrm{d}$ ratio. While milled clay had very short and damage rods with less aspect ratio $(1 / d)[1,13]$. The effect of aspect ratio(l/d) was reflected on yield of clay, where crushed clay had higher yield of clay than milled clay at fresh and salty water as illustrated in table 4.

Table 4: Rheological properties for attapulgite clay

\begin{tabular}{|c|c|c|c|c|}
\hline \multirow[b]{2}{*}{ property } & \multicolumn{2}{|c|}{ Crushed Clay } & \multicolumn{2}{|c|}{ Milled Clay } \\
\hline & D.W & S. W & D.W & S. W \\
\hline$\underline{\mathrm{PV}(\mathrm{cP})}$ & 3.7 & 2.95 & 0.8 & 1 \\
\hline$\frac{\text { YP }}{(1 b f / 100 f t 2)}$ & 15.89 & 12.5 & 3.51 & 2.14 \\
\hline$\frac{10 \mathrm{~S} \text { gel }}{(1 \mathrm{bf} / 100 \mathrm{ft} 2)}$ & 20.12 & 11.7 & 3.6 & 3.7 \\
\hline$\frac{10 \mathrm{Min} . \mathrm{gel}}{(\mathrm{lbf} / 100 \mathrm{ft} 2)}$ & 11 & 11.33 & 6.4 & 6.9 \\
\hline$\underline{\mathrm{A} . \mathrm{V}(\mathrm{cP})}$ & 19.28 & 15 & 3.15 & 3.1 \\
\hline Stability & 69 & - & 36 & - \\
\hline$\frac{\text { Yield of }}{\text { Clav }}$ & 101.94 & 89.87 & 41.99 & 38.4 \\
\hline Clay \% & 5.43 & 6.00 & 12.6 & 13.47 \\
\hline $\mathrm{pH}$ & 7 & 7 & 7 & 7 \\
\hline
\end{tabular}

For attapulgite clay that separated using wet sieving process, the apparent viscosity was (15.83 and $12.06 \mathrm{cp})$ and yield of clay (94.21 and 79.93) barrel/ton at fresh and Comparing with crushed clay; milled clay had reduced more than $80 \%$ of the apparent viscosity due to applied dry milling process which made change in attapulgite aspect ratio (1/d). Therefore; wet milling was adopted in attapulgite preparation process and dry milling is not recommended. salty water respectively. These values were lower than that for crushed attapulgite resulted from dispersing agents process. Although close content of quartz within purified clays which resulted from both separation processes, there was difference in their rheological properties. This difference results from the variation in attapulgite dispersion level between the produced clay by dispersing agents and wet sieving processes. These results are a good demonstration of the importance effect of attapulgite dispersion on the rheological properties of drilling fluid.
Table5: Rheological properties for attapulgite clay resultant from wet sieving process.

\begin{tabular}{|c|c|c|}
\hline property & D.W & S. W \\
\hline PV (cP) & 3.2 & 2.03 \\
\hline YP (lbf/100ft2) & 12.87 & 10.25 \\
\hline 10S gel (lbf/100ft2) & 13.2 & 7.66 \\
\hline $\begin{array}{c}\text { 10 Min. gel } \\
\text { (lbf/100ft2) }\end{array}$ & 13.3 & 8.66 \\
\hline A.V (cP) & 15.83 & 12.06 \\
\hline Stability & 69.5 & - \\
\hline Yield of Clay bbl/ton & 94.21 & 79.93 \\
\hline Clay \% & 5.86 & 6.72 \\
\hline pH & 7 & 7 \\
\hline
\end{tabular}

\subsection{Yield of Process Result}

The dry sieving failed in separation process therefore its yield was zero. While, the yield of dispersing agents process did not exceed $7 \%$ for both mild and crushed clay. So, this process characterized as low yield process comparing to the real clay mineral content more than $36 \%$ exists within attapulgite rock. The main reason for

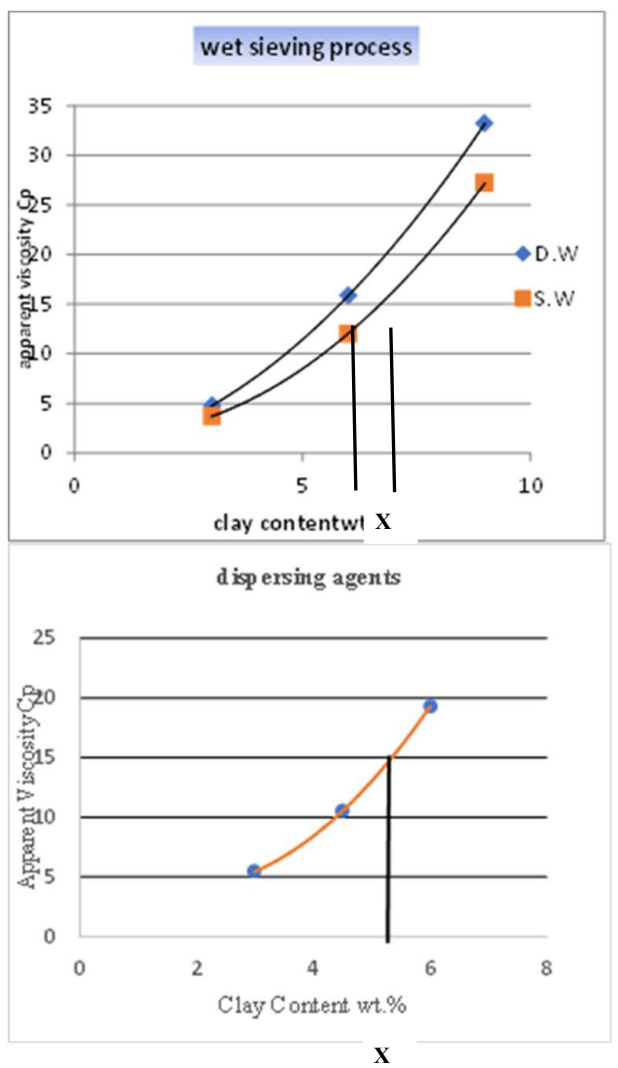

Figure 7: The relation between apparent viscosity and clay content. 
this result could be due to the high calcite content which negatively affecting the dispersion of clay mineral causing loos high clay amount [5].

The yield of wet sieving process reached more than $40 \%$. This value presents pure clay mineral plus quartz with silt-size since that quartz with silt size is difficult to washed and separated from clay completely by wet sieving process [18].

\section{Conclusion}

Quality and quantity are important criteria in successful decision making to select certain preparation process. Actually, there is no process could reach these criteria, therefore; balancing is very important for any process selection or process layout. In this work, dry sieving, wet sieving and dispersing agents processes were used in attapulgite preparation process to be suitable for oil wells drilling fluids. Many vital decisions were successfully reached in this work: -

1- Dry milling is distractive process for attapulgite crystal structure.

2- Dry sieving is unsuccess process in clay separation or concentration process. Thus, it is not recommended.

3- In dispersing agents process, milled clay had low apparent viscosity and classified as moderate clay according to yield of clay $[6,19]$.

4- Wet milling didn't cause significant damage for attapulgite crystal structure; therefore, it is adopted in attapulgite clay preparation process.

5- Despite of the dispersing agents process had more yield of clay; but it is not recommended because it has low yield of process. While wet sieving process had high yield of clay and higher yield of process.

6- The wet sieving is more acceptable process to prepare Iraqi attapulgite clay for utilizing in oil wells drilling fluid.

Table 6: Nomeaclature used in the paper.

\begin{tabular}{ccc}
\hline AV & Apparent Viscosity & $\mathrm{cP}$ \\
PV & Plastic Viscosity & $\mathrm{cP}$ \\
YP & Yield Point & $\left(\mathrm{lbf} / 100 \mathrm{ft}^{2}\right)$ \\
Ө600 & dial reading at 600 & - \\
& rpm \\
Ө300 & dial reading at 300 & - \\
\hline
\end{tabular}

\section{References}

[1] A. Neaman and A. Singer, "Rheological properties of aqueous suspensions of palygorskite," PP 427-436,2000.

[2] E. W. Lane, "Report of the subcommittee on sediment terminology," Eos, Transactions American Geophysical Union, vol. 28, pp. 936-938, 1947.

[3] A. S. S. Committee, Drilling fluids processing handbook: Gulf Professional Publishing, 2005.

[4] B. A. Wills and J. Finch, Wills'mineral processing technology: an introduction to the practical aspects of ore treatment and mineral recovery: 7th Edition, Elsevier Science \& Technology Books,2006.

[5] F. Bergaya and G. Lagaly, Handbook of clay science: ch7th, pp385-409,2013.

[6] C. A. M. Baltar, A. B. da Luz, L. M. Baltar, C. H. de Oliveira, and F. J. Bezerra, "Influence of morphology and surface charge on the suitability of palygorskite as drilling fluid," Applied Clay Science, vol. 42, pp. 597-600, 2009.

[7] M. E. Fleet, W. A. Deer, R. A. Howie, and J. Zussman, "Rock-forming minerals"(2nd edition), v. 5B, non-silicates, PP 108-135,1996.

[8] C. Mohapatra Mineral Processing, ch.1, Kisii University,2017.

[9] D. A. Jacobs and H. R. Hamill, "Attapulgite clay dispersions and preparation" United States Patent no. 3,509,066, Apr. 28, 1970.

[10] F.-s. Zhou, T.-q. Li, Y.-h. Yan, C. Cao, L. Zhou, and Y. Liu, "Enhanced viscosity of aqueous palygorskite suspensions through physical and chemical processing," Advances in Materials Science and Engineering, vol. 2015, 2015.

[11] E. G. Kirali and O. Lacin, "Statistical modelling of acid activation on cotton oil bleaching by Turkish bentonite," Journal of Food Engineering, vol. 75, pp. 137-141, 2006.

[12] W. Haden, "Attapulgite: properties and uses," Clays and Clay Minerals, vol. 10, pp. 284-290, 1961.

[13] X. Zhang, W. Jiang, X. Wu, B. Shi, B. Yang, X. Jia, et al., " Effect of ultrafine grinding on the crystal structure and morphology of attapulgite clay. Non-Met. Mines (Chin.) 27 (3), PP14-15, 2004.

[14] Metso mining and aggregates, basics in mineral processing, Edition 11, 2018.

[15] M. Al-Haidarey, I. Abdumunem, M. Abbas, and N. Al-Ansari, "The trophic state index of Bahr Al-Najaf depression reservoir, Iraq," Journal of Environmental Hydrology, Vol. 24, PP1-10, 2016. 
[16]

P. Sampson, D. Parker, and D. Ruff, "Purified attapulgite clay," United States Patent, Patent No. 6,130,179,2000

[17]

The Pharmacopoeial Discussion Group, annex 12 to note for evaluation and recommendation of pharmacopoeial texts for use in the ich regions on analytical sieving general chapter, European Medicines Agency, pp3-13,2009.
[18] United States Environmental Protection Agency (USEPA), A Citizen's Guide to Soil Washing, EPA 542-F-96-002, 1996.

[19] Souza Santos P., Tecnologia de Argilas, Volume 2. Editora Edgard Blücher, São Paulo, 1975.

\section{معاملة الأتبلغايث العراقي لأستعماله كسائل حفر:در اسة مقارنة احد فليح حسين 1، ، عبل الخالق فوزي حمود²، اساور عبد الرسول الواسطي 3 \\ قسم هندسة الأنتاج و المعادن ، الجامعة التكنولوجية، بغداد، العراق. قسم هندسة الأنتاج و المعادن، الجامعة التكنولوجية، بغداد، العراق. قسم تكنولوجيا النفط، الجامعة التكنولوجية، بغداد، العراق.} الباحث المثل: : دحد فليح حسين، Afh_uot@yahoo.com

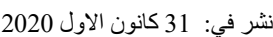

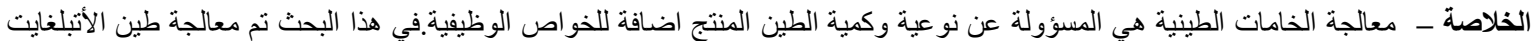

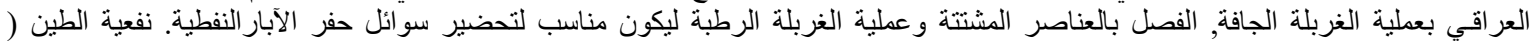

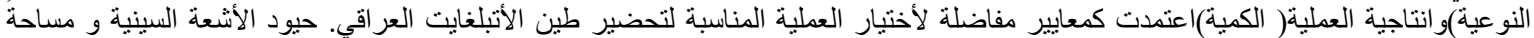

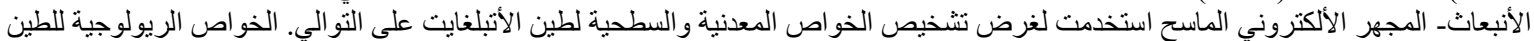

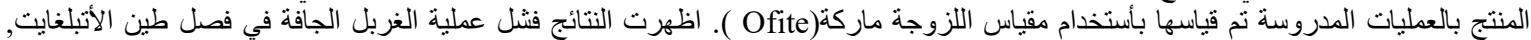

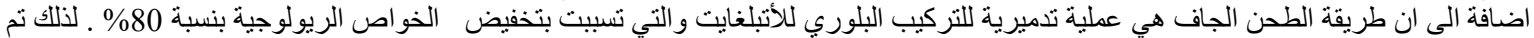

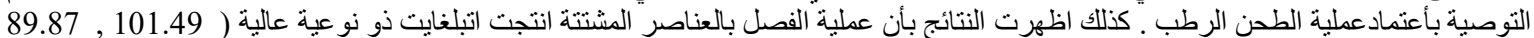

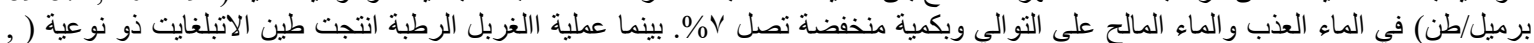

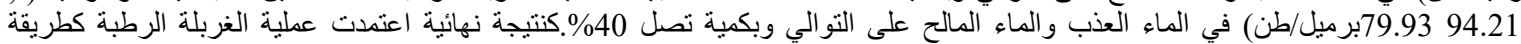
لتحضير طين الأتبلغايت العر اقي ليكون مناسب للأستخدام في سو ائل حفر آبار النفط.

الكلمات الرئيسية _-طين الأتبلغايت العر اقي، الغربلة الجافة، الغربلة الرطبة، العناصر المشتتة، الخواص الريولوجية" 